University of Nebraska - Lincoln

DigitalCommons@University of Nebraska - Lincoln

NEW RECORDS FOR ACERIA ANTHOCOPTES (ACARI: ERIOPHYIDAE) OCCURRING ON CANADA THISTLE IN COLORADO, NEBRASKA, AND WYOMING, U.S.A.

G. J. Michels Jr.

Texas Agricultural Experiment Station, gmichels@tamu.edu

V. A. Carney

Texas Agricultural Experiment Station, vacarney@ag.tamu.edu

J. Lydon

USDA, Agricultural Research Service, John.Lydon@ars.usda.gov

Ronald Ochoa

USDA, ARS Systematic Entomology Laboratory, ron.ochoa@ars.usda.gov

R. L. Renn

Department of the Army, Directorate of Environmental Compliance and Management, Robin.Renn@us.army.mil

Follow this and additional works at: https://digitalcommons.unl.edu/usdaarsfacpub

Michels, G. J. Jr.; Carney, V. A.; Lydon, J.; Ochoa, Ronald; and Renn, R. L., "NEW RECORDS FOR ACERIA ANTHOCOPTES (ACARI: ERIOPHYIDAE) OCCURRING ON CANADA THISTLE IN COLORADO, NEBRASKA, AND WYOMING, U.S.A." (2008). Publications from USDA-ARS / UNL Faculty. 2112.

https://digitalcommons.unl.edu/usdaarsfacpub/2112

This Article is brought to you for free and open access by the U.S. Department of Agriculture: Agricultural Research Service, Lincoln, Nebraska at DigitalCommons@University of Nebraska - Lincoln. It has been accepted for inclusion in Publications from USDA-ARS / UNL Faculty by an authorized administrator of DigitalCommons@University of Nebraska - Lincoln. 


\title{
NEW RECORDS FOR ACERIA ANTHOCOPTES (ACARI: ERIOPHYIDAE) OCCURRING ON CANADA THISTLE IN COLORADO, NEBRASKA, AND WYOMING, U.S.A. ${ }^{1}$
}

\author{
G. J. Michels Jr., ${ }^{2}$ V. A. Carney, ${ }^{2}$ J. Lydon, ${ }^{3}$ R. Ochoa, ${ }^{4}$ and R. L. Renn ${ }^{5}$
}

ABSTRACT: Canada thistle [Cirsium arvense (L.) Scop.] growing in eastern Colorado, Wyoming and western Nebraska were surveyed for the presence and distribution of Aceria anthocoptes (Nal.). Of the 34 sites surveyed in 2004, mites were abundant at $42 \%$, present in lesser numbers at $52 \%$, and not present at $6 \%$ of the sites. In 2005, two new sites were added and ten sites sampled in 2004 were revisited. Of these 12 sites, mites were abundant at $17 \%$, present to a lesser extent at $58 \%$, and not present at $25 \%$ of the sites. The results demonstrate that Canada thistle growing in this region commonly harbor $A$. anthocoptes. How long $A$. anthocoptes has been present in this region is unknown, however, anecdotal evidence demonstrating a dramatic decline in the population of Canada thistle at one Colorado site from 2000 to 2007 suggests that the mite may have been present since 2002 .

KEY WORDS: Aceria anthocoptes, Canada thistle, biological control, state records

Canada thistle [Cirsium arvense (L.) Scop.], is a perennial composite that is native to southeastern Europe and the eastern Mediterranean. Presently it occurs throughout most temperate regions of the world (Moore 1975; Holm et al., 1997). While the date of its introduction into the United States is unknown, Canada thistle was recognized as a troublesome weed as early as 1795 when Vermont established legislation for its control (Moore 1975). Based on the review of weed lists from the United States and southern Canada, Canada thistle was the most frequently listed noxious weed out of 45 noxious weeds included in the study; demonstrating that it continues to be of concern in the temperate regions of North America (Skinner et al., 2000).

Because of the expense involved in the use of chemical and/or cultural methods for weed control, biological control agents are generally considered the primary option for invasive weed control in natural systems. Several insect enemies of Canada thistle have been developed and/or deployed in an effort to control this invasive weed, such as leaf- and bud-feeding beetles [Altica carduorum GuerinMeneville, Lema cyanella (L.), and Cassida rubiginosa Muller, Coleoptera: Chrysomelidae], stem-boring beetles (Ceutorhynchus litura (F.), Coleoptera: Curcu-

\footnotetext{
${ }^{1}$ Received on February 6, 2008. Accepted on February 25, 2008.

${ }^{2}$ Texas Agricultural Experiment Station, 2301 Experiment Station Road, Bushland, Texas 79012 U.S.A. E-mails: gmichels@tamu.edu, vacarney@ag.tamu.edu, respectively.

${ }^{3}$ Sustainable Agricultural Systems Laboratory, U.S. Department of Agriculture, Agricultural Research Service, Beltsville Agricultural Research Center, Beltsville, Maryland 20705 U.S.A. E-mail: John.Lydon@ars.usda.gov

${ }^{4}$ Systematic Entomology Laboratory, U.S. Department of Agriculture, Agricultural Research Service, Beltsville Agricultural Research Center, Beltsville, MD 20705 U.S.A. E-mail: Ron.Ochoa@ars. usda.gov
}

${ }^{5}$ Department of the Army, Directorate of Environmental Compliance and Management, Fort Carson, CO 80913 U.S.A. E-mail: Robin.Renn@us.army.mil 
lionidae), seed-feeding beetles (Rhinocyllus conicus (F.), Coleoptera: Curculionidae), stem-galling flies (Urophora spp., Diptera: Tephritidae), and other insects (Rees 1991; Julien and Griffiths 1998; Campobasso et al., 1999; Gassmann 2005). The release and predation of these insect enemies of Canada thistle has had an effect, but satisfactory control has yet to be obtained (Michels, pers. obs).

Recently, an eriophyid mite, Aceria anthocoptes (Nal.), that attacks Canada thistle was reported in the United States (Ochoa et al., 2001). This is the only Aceria mite species known to attack Canada thistle (Petanoviæ et al., 1997; Magud et al., 2007) and preliminary results suggest that the mite is host specific (Ochoa et al., 2001). Infestations of $A$. anthocoptes on Canada thistle can result in leaf bronzing, epinasty, and dessication (Rancic et al., 2006). As part of an ongoing program to control noxious weeds on Federal installations in Colorado and Wyoming, consideration has been given to the release of $A$. anthocoptes in natural areas at these installations to further increase the predatory pressure on Canada thistle. Although $A$. anthocoptes is widely distributed in the Mid-Atlantic region and has been reported in the north-central states of Minnesota and North Dakota (Ochoa et al., 2001), it was unknown if the mite was present in Colorado, Wyoming, and Nebraska. The objective of this study was to assess the presence and distribution of $A$. anthocoptes in the Colorado-Wyoming-Nebraska region.

\section{METHODS}

Collection and processing of samples. Samples of Canada thistle were collected from a total of 36 different sites located in Colorado, Nebraska, and Wyoming during August of 2004 and 2005 (Table 1, Fig. 1). Samples consisted of the stems, leaves, and flowers from the top half of the above-ground portion of the plants. Upon collection, samples were placed in plastic bags and held over ice during transport to the laboratory; where they were held at $4^{\circ} \mathrm{C}$ until examined.

Approximately $25 \mathrm{~g}$ of plant material was transferred to a $2.5 \mathrm{~L}$ flask, $250 \mathrm{ml}$ of water was added, and the contents of the flask were vigorously shaken for $15 \mathrm{~s}$. The water suspension was vacuum filtered through a $0.8 \mu$ Supra Gellman membrane. The suction was removed after all the water passed through the filter but before the membrane dried. A second wash as described above with a fresh membrane immediately followed. The two membranes were then examined under a dissecting microscope for the presence of eriophyid mites. When present, mite specimens were collected, transferred to $70 \%$ ethanol, and stored at $4^{\circ} \mathrm{C}$. An additional $25 \mathrm{~g}$ sample of plant material was processed as above if no mites were observed on the first set of membranes. No attempt was made to obtain an exact count of the mites present on the membranes. However, the relative abundance of the mites was assessed as follows: not present (NP), no mites observed; present $(\mathrm{P})$, mites present but careful and extensive searching of the membrane was required to retrieve mites, and abundant (A), high numbers of the mites were collected in a short period of time, many remained uncollected. 


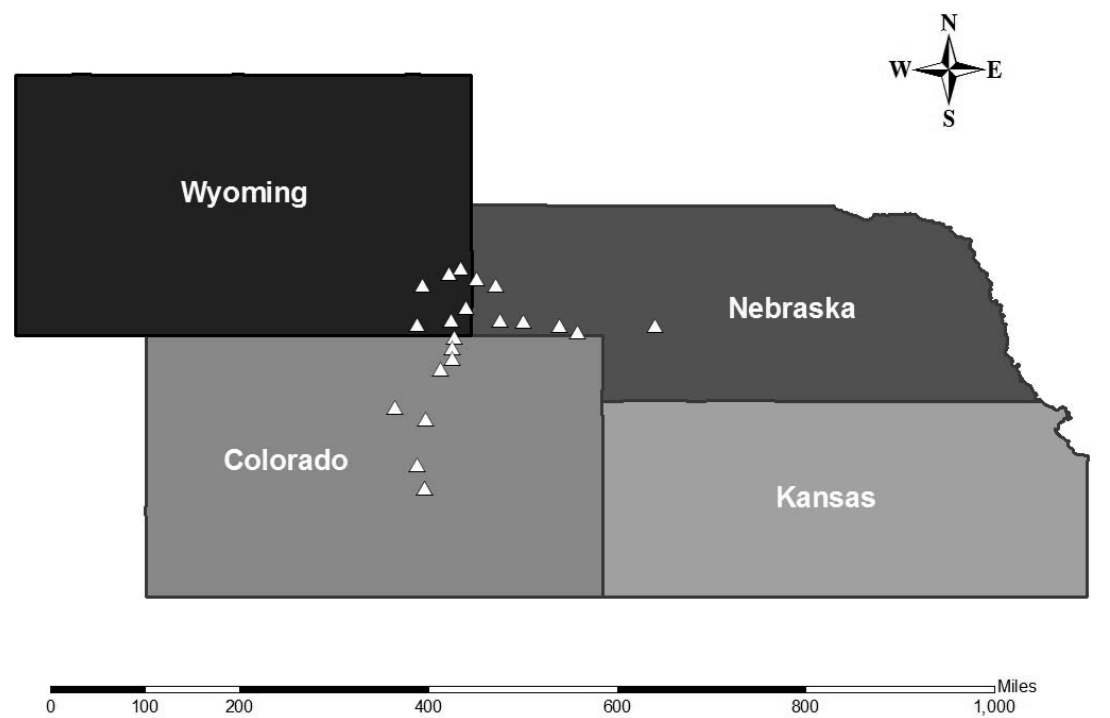

Fig. 1. Map showing sites in Wyoming, Colorado, and Nebraska where Canada thistle (Cirsium arvense) plant material was collected.

Canada thistle population density measurements. At one site, designated ARA1 at Ft. Carson, the population density of Canada thistle was monitored from 2000-2007. For each year, the perimeter of the Canada thistle infestation was mapped using either Satlock backpack (2000-2005) or Trimble GeoXT handheld GPS units (2006 and 2007). Once the perimeter was mapped, the area of the infestation was gridded using GPS data collection software, and samples were taken from each grid square by tossing a $1 / 2$ meter PVC sampling square toward the center of the block. All Canada thistle plants within the sampling square were counted. The number of samples taken in a given year depended on the size of the infestation perimeter, with the grid size remaining constant at 25 $\mathrm{m}^{2}$.

Microscopic examination of specimens. Mites collected from the Canada thistle samples and stored in $70 \% \mathrm{EtOH}$ were prepared for microscopic examination as described in Amrine and Mason (1996). The prepared slides were examined under a compound microscope and the identification of the mites was based on standard mite taxonomic keys (Amrine et al., 2003) and specific morphological traits for the species as reported by Petanoviæ et al. (1997). 
Table 1. Survey of Aceria anthocoptes on Canada thistle (Cirsium arvense) growing in Colorado (CO), Wyoming (WY), and Nebraska (NE) in 2004 and 2005. Shaded rows indicate sites that were visited once during both years.

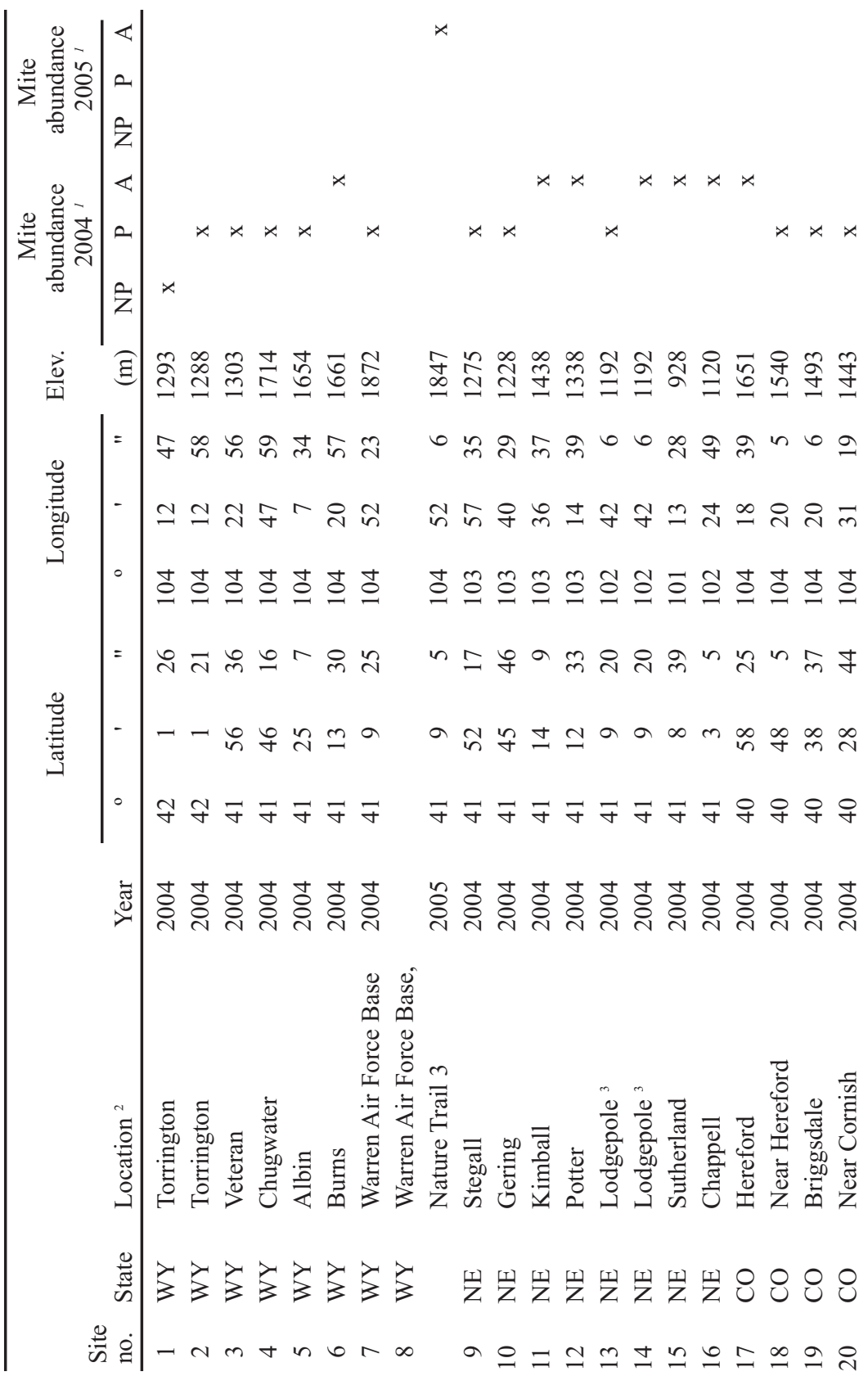




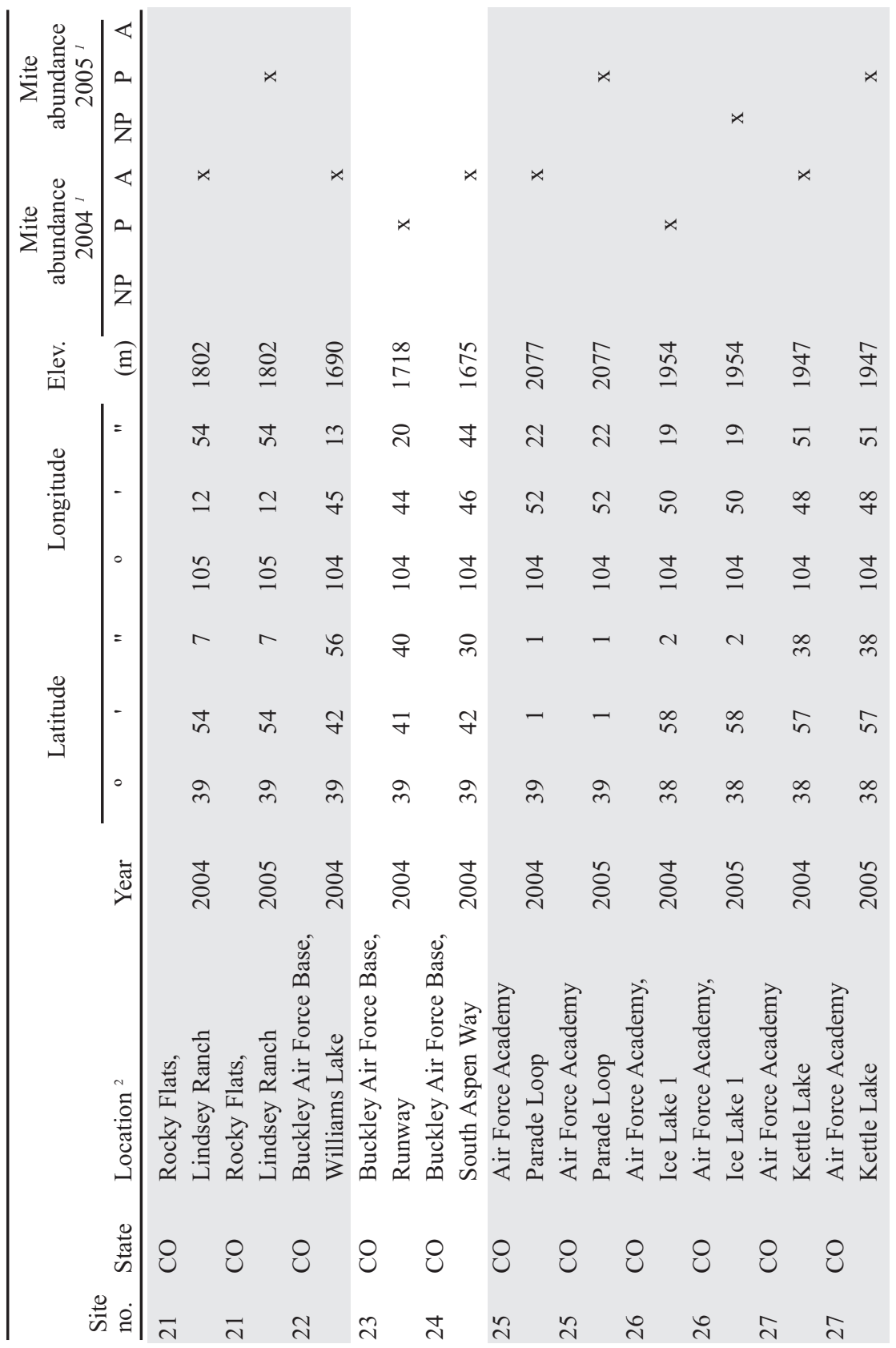




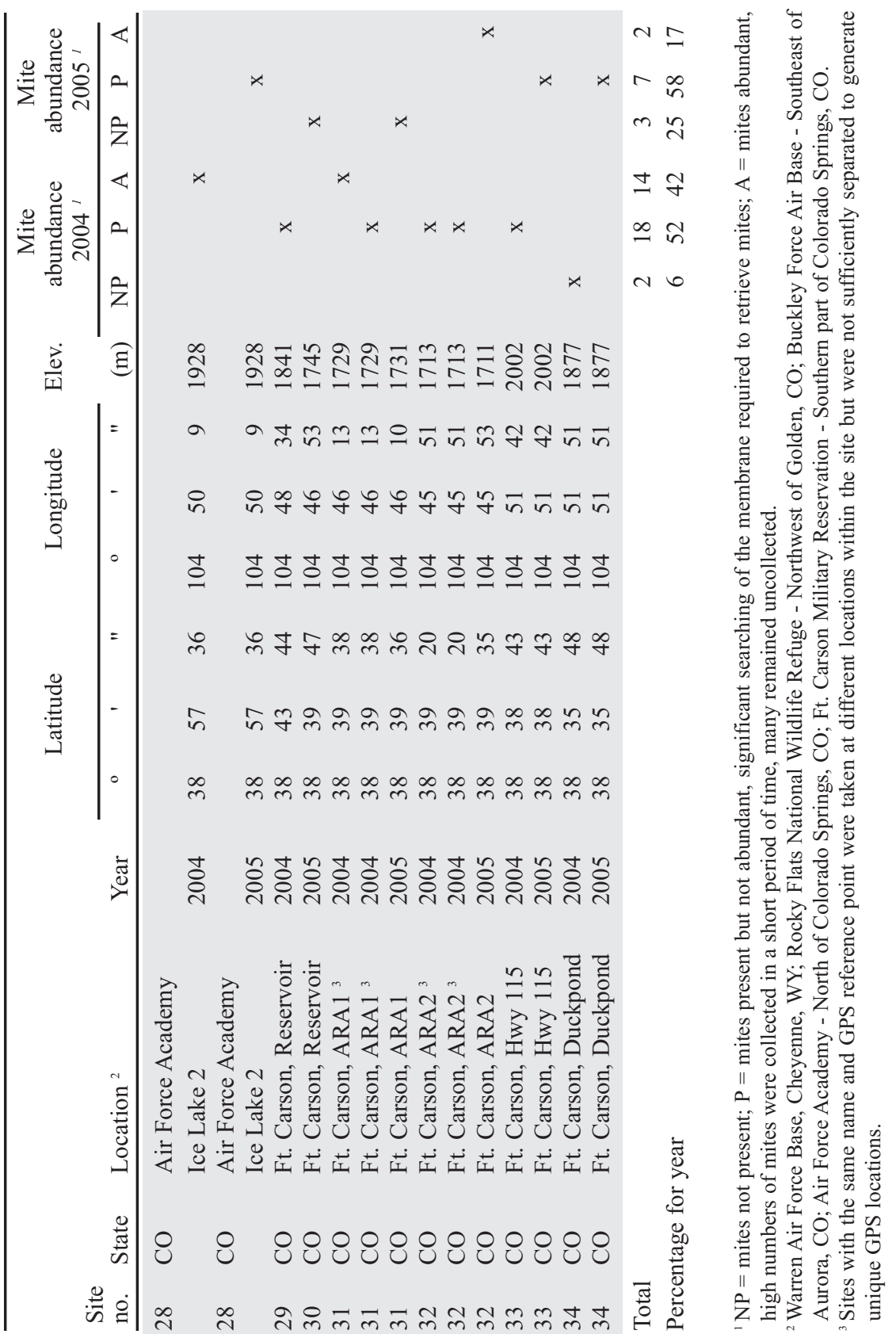




\section{RESULTS}

Most plant samples collected from populations of Canada thistle located at 34 different sites in three different north-central states during 2004 and 2005 harbored mites and insects of various species. The eriophyid mites collected from the Canada thistle specimens were determined to be of the vagrant type as there were no gall formations present on any of the specimens examined. All eriophyid mites present on the plant tissue exhibited vermiform bodies with posterior opisthosoma annuli, continuous and subequal dorsoventrally (Fig. 2A). The adult females, varying from $130-190 \mu \mathrm{m}$, had a prodorsal shield with a median line that was complete, uninterrupted and usually straight; two admedian lines that were complete, uninterrupted and slightly curved at the posterior edge; and two submedian lines, one to each lateral side curved close to the bases of the dorsal tubercle of the scapular setae (Fig. 2B). The genital coverflap was ornamented with one rank of lineate ribbing (Fig. 2C). All the above characteristics are consistent with those of $A$. anthocoptes (Ochoa et al., 2001; Amrine et al., 2003; Rancic et al., 2006; Magud et al., 2007).

This mite species was found at $94 \%$ of the 34 Canada thistle populations sampled in 2004; it was abundant at $42 \%$ of the sites, present in low numbers at $52 \%$ of the sites, and not present at $6 \%$ of the sites (Table 1). Mite populations declined at $70 \%$ of the sites resurveyed in 2005 . Of the two new sites surveyed in 2005, A. anthocoptes was abundant at one and not present at the other (Table 1). It should be noted that these were one-time samples for the entire year, and although they do give an indication of mite abundance, a thorough sampling of each site over the course of the growing season may have yielded different mite abundance results.

The Canada thistle population located at Ft. Carson, ARA 1 was monitored from 2000 to 2007. The average Canada thistle densities were 14, 13, 5, 1, 3, 4, 2 , and 0 plants $\mathrm{m}^{-2}$, respectively.

\section{DISCUSSION}

The surveys conducted in 2004 and 2005 confirmed the presence of $A$. anthocoptes in Colorado, Nebraska and Wyoming. Based on the high frequency of occurrence in Canada thistle populations reported here and in a previous survey conducted in the mid-Atlantic region (Ochoa et al., 2001), it appears that A. anthocoptes is widely distributed across the U.S. Whether it was introduced into the U.S. from Canada into the west and carried across the continent by the prevailing winds or inadvertently distributed from the east to the west via contaminated feed stock or movement of vehicles and/or people remains unknown.

Interestingly, earlier observations (2002) of plants at this site by one of the authors (Michels, unpublished) revealed damage similar to what was later associated with infestations of $A$. anthocoptes (i.e., leaf bronzing, epinasty, dessication and stunting). As no other biocontrol agent has become established in significant numbers at this site, the general decline over the years and ultimate disappearance of Canada thistle at this site may indicate that A. anthocoptes may have been present in Colorado earlier than 2004. 

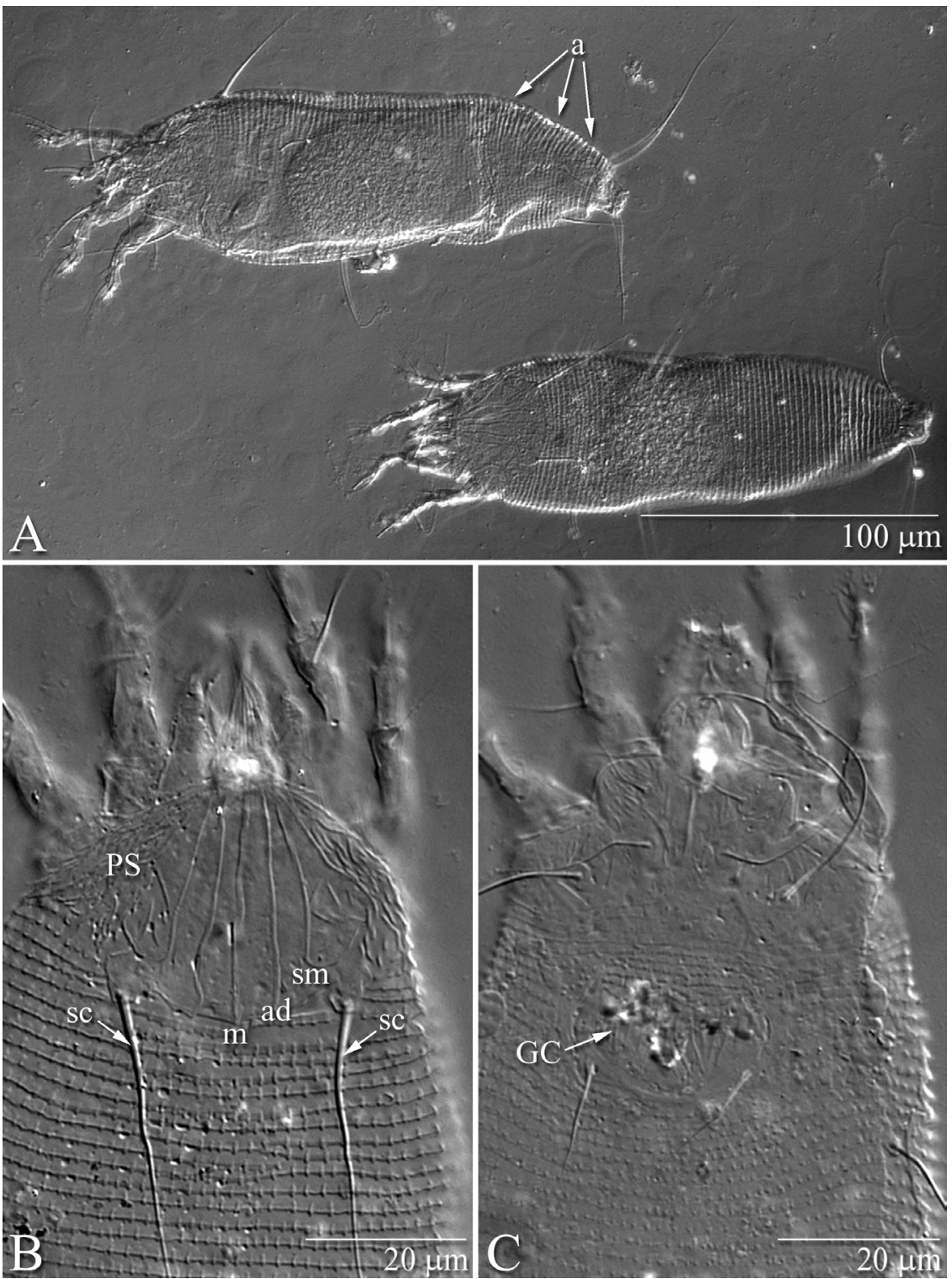

Fig. 2. Microphotograph of Aceria anthocoptes females displaying dorsal, ventral, and lateral views: A. general view of dorsal-ventral and lateral sides; B. view of prodorsal shield; and $\mathrm{C}$. view of genital region. $\mathrm{a}=$ annuli; $\mathrm{ps}=$ prodorsal shield; $\mathrm{m}=$ median; $\mathrm{ad}$ $=$ admedian; $\mathrm{sm}=$ submedian; $\mathrm{sc}=$ scapular setae; $\mathrm{gc}=$ genital coverflap . 
The benefits of using A. anthocoptes in the biological control of Canada thistle have yet to be determined. Working within the geographical areas in Colorado where the mite has now been documented to be present, studies are underway to determine the impact of the mite on previously uninfested Canada thistle populations. In addition, studies by our group and others (Richard W. Hansen, USDA-APHIS-PPQ, Ft. Collins, $\mathrm{CO}$, pers. comm.) are being conducted to determine the genetic relationship of $A$. anthocoptes to eriophyid mites found on closely related Cirsium species.

\section{ACKNOWLEDGMENTS}

Research reported in this paper was supported in part by a grant from the U.S. Department of Defense through the U.S. Fish and Wildlife Service (Agreement 601814J251). The authors thank Bruce Rosenlund, U.S. Fish and Wildlife Service, Project Leader, CO FWAO; Tom Warren, Director, Directorate of Environmental Compliance and Management at Ft. Carson; Dr. Brian Mihlbachler, Natural Resources Manager, U.S. Air Force Academy; Floyd Hatch, Natural and Cultural Resources Coordinator, Buckley Air Force Base; Cathy Pesenti, Environmental Management Flight, F. E. Warren Air Force Base; and Amy Thornburg, U.S. Fish and Wildlife Service, Rocky Flats National Wildlife Refuge site for their continued support and assistance in the noxious weed biological control implementation program.

\section{LITERATURE CITED}

Amrine J. W. and D. C. M. Manson. 1996. Preparation, mounting and descriptive study of eriophyid mites. pp. 383-396. In, E. E. Lindquist, M. W. Sabelis, and J. Bruin (Editors). Eriophyoid mites: Their biology, natural enemies and control. Volume 6. World Crop Pests. Elsevier Science BV. Amsterdam, The Netherlands. 822 pp.

Amrine, J. W. Jr., T. A. H. Stasny, and C. H. W. Flechtmann (Editors). 2003. Revised keys to world genera of Eriophyoidea (Acari: Prostigmata). Indira Publishing House. West Bloomfield, Michigan, U.S.A. 244 pp.

Campobasso, G., E. Colonel, L. Knutson, G. Terragitti, and M. Cristofaro. 1999. Wild plants and their associated insects in the Palearctic Region, primarily Europe and the Middle East. U.S. Department of Agriculture, Agricultural Research Service No. ARS-147. Springfield, Virginia, U.S.A. 243 pp.

Gassmann, A. 2005. Classification of thistle species and potential for biological control of Cirsium arvense in New Zealand. Annual Report. CABI Bioscience Switzerland Centre. 25 pp.

Holm, L., J. Doll, E. Holm, J. Pancho, and L. Herberger. 1997. World Weeds, Natural Histories and Distribution. J. Wiley \& Sons, Inc. New York, NY, U.S.A. 1129 pp.

Julien, M. H. and M. W. Griffiths. 1998. Biological Control of Weeds: A World Catalogue of Agents and their Target Weeds. 4th Edition. CABI Publishing. Oxon, England, UK. 223 pp.

Magud, B. D., Z. L. Stanisavljević, and R. U. Petanović. 2007. Morphological variation in different populations of Aceria anthocoptes (Acari: Eriophyoidea) associated with the Canada thistle, Cirsium arvense, in Serbia. Experimental and Applied Acarology 42:173-183.

Moore, R. J. 1975. The biology of Canadian weeds. 13. Cirsium arvense (L.) Scop. Canadian Journal of Plant Sciences 55:1033-1048.

Ochoa, R., E. F. Erbe, W. P. Wergin, C. Frye, and J. Lydon. 2001. The presence of Aceria anthocoptes (Nalepa) (Acari: Eriophyidae) on Cirsium species in the United States. International Journal of Acarology 27:179-187.

Petanović, R., J. Boczek, and B. Stojnia. 1997. Taxonomy and bioecology of eriophyids (Acari: Eriophyoidea) associated with Canada thistle, Cirsium arvense (L.) Scop. Acarologia 38:181-191.

Rancic, D., B. Stevanovic, R. Petanoviæ, B. Magud, I. Tosevski, and A. Gassmann. 2006. Anatomical injury induced by the eriophyid mite Aceria anthocoptes on the leaves of Cirsium arvense. Experimental and Applied Acarology 38:243-253.

Rees, N. E. 1991. Biological control of thistles. pp. 264-273. In, L. F. James, J. O. Evans, M. H. Ralphs, and R. D. Child (Editors). Noxious Range Weeds. Westview Press, Inc. Boulder, Colorado, U.S.A. $466 \mathrm{pp}$.

Skinner, K., L. Smith, and P. Price. 2000. Using noxious weed lists to prioritize targets for developing weed management strategies. Weed Science 48:640-644. 